間に正規型分布が予想される。

泥漿濃度と粒子の分布状態に関して検べた結果, 最 大飛散距離は濃度の増加で大きくなるが, 標準偏差 $\sigma$ は漸次減少して粉体の中央集中度は良好になる傾向が 見出される。

その他, 回転子内壁に拈ける泥漿の状態について考
察せる一部を報告する予定である。

また，粉体成形時における密度变化， 压伝播現象， 粉体の崩壊現象について現在得られた結果につき述 べ，粉体の圧縮性 (Compactibility) の表示法として, 成形体厚さ零に拈ける密度といらすのを考竞得たので それについて述べることにする。

\title{
24. 球体の配列状態と充冝率
}

粉体の成型に関して, 等大球体の比較的簡単な特種 な配列状態に対する気孔率を計算した報告は既に見ら れるが，広範囲にわたる配列状態と気孔率との関係を 表わす一般式についてはいまだ報告が無いようであ る。

演者は $X Y$ 平面上に規則的に配列された等大球体 が，その配列状態を $Z$ 軸方向に繰り返し，各球体が その下層の 3 ヶの球体に接触する場合について, 配列 状態と充填率との関俰式を誘導した。

$\boldsymbol{X} \boldsymbol{Y}$ 平面上の 3 ヶの球体閒の中心距離を, それぞれ $a, b, c$ とすれば, 気孔容積と球体総容積との比 $P_{0}$ は 下式で表わされた。

$$
P_{0}=\frac{3}{4 \pi} \sqrt{4 a^{2} b^{2}-\left(a^{2}+b^{2}-c^{2}\right)^{2}-\frac{1}{4} a^{2} b^{2} c^{2}-1}
$$

\section{大阪工業技術試験所 大 石 行 理}

但し, 球体の半径を 1 とする。

上式中 $a, b, c$ の值の組合せには制限があり，これ に対する吟味を行つた。

次に，一般に粉体を節分して，粒度を揃える場合， その粒度は相隣つた 2 ケの節の目開きの間に分布する 筈であつて，この場合には上式により厳密に配列状態 と充填率との関係を表わし難い。

これに対して，2 種の球体の混合について，上と同 様の計算を試み，下式を誘導した。

$$
P_{1}=\frac{3 \sqrt{\left(1+r_{2}\right)^{2}\left\{4 a^{2} b^{2}-\left(a^{2}+b^{2}-c^{2}\right)^{2}\right\}-a^{2} b^{2} c^{2}}}{4 \pi\left(1+r_{2}^{3}\right)}-1
$$

但し， $r_{2}$ は第 2 の球の半径である。

上の式について, $a, b, c$ 拉よび $r_{2}$ の值の変化に対 する $P_{0}$ 又は $P_{1}$ の值の変化の計算例を示した。

\section{5. 塩素処理による陶磁器原料の脱鉄}

\section{工業技術庁東京工業試験所}

酸化鉄含有量の多い低品位原料を用いて，白色で透 光性の良い陶磁器を得る目的でこの研究に着手した。 まず各種の原料を成形し石英管に詰め，電気炬中て

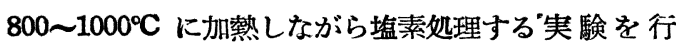
い，非常に良好な結果を得た。すなわち脱鉄率は80〜 90\%，塩素の使用量は理論值の 1.5 倍程度で济むこと があきらかとなつた。よつて更に規模を大きくし 1.2 $\mathrm{m} \times 2.8 \mathrm{~m} \times 2.0 \mathrm{~m}$ の中間試験炉を建設し, その中へ $40 \mathrm{~cm} \times 40 \mathrm{~cm} \times 38 \mathrm{~cm}$ のマッフルを設置し，これに実 際工場で成形した皿, 椀等の試料を拾数 $\mathrm{kg}$ 詰め, 高 温に加熱しつ」塩素処理する実験を行い，㙁素の消費 量, 試料の脱鉄率その他の数值を測定検討した。一方 こょで得た脱鉄試料は,これに上薬をかけて本焼して， その成果を比較検討した。その結果, 脱鉄率は試料に

\section{○鈴木 䇠・富沢 敏・落合康男}

より多少差異はあるが，70〜80\%程度，塩素の消費㱶 も試料に対し数\%以下の程度まで節約することができ た。各実験中しばしばマッフル, 煙道等のガス分析を 行い, 㙁素その他のガスの濃度变化に注意した。

以上の中間試験結果を, 更に確実なものにする為小 試験片について G.E. 自記分光々度計により脱鉄と分 光透過率执よび反射率との関係を求めて比較検討し た。

一方塩素処理温度を低下させても，な打良好な脱鉄 率を得る為に, 予めこれに崖素等の還元性物質を添加 して㙁素処理する実験を行い, 100 200ํㄷ 処理温度 を低下し得ることを確めた。

演者らは以上の諸実験の諸条件とその結果につき報 告する予定である。 


\section{6. 隐磁器原料の加圧水熱法による脱鉄}

オートクレーブを使用して粘土中の酸化鉄を脱鉄精 製し, 粘土の品質向上を図らんとし, 担当者は前にこ の效果を知るために鳳来寺陶石と涉草陶石を試料とし て，陶石中の鉄について脱鉄実験を行つてみた。その 結果については, すでに名古屋工業大学々報 (昭和 26 年(3) 264）に発表したが，前試料の陶石中の鉄の脱鉄 効果は若干期待しろる結果を示した。そこで, 更に本 研究の目的である粘土について, 陶石と同様な実験を 行い, その実験結果を検討してみた。

本研究に使用した粘土としては耐火物方面に相当重 視されている西加茂郡地方の比較的含有鉄の多いるの を択んで実験してみた。研究方法としては，まず試料 100 メッシュ全通のものをオートクレーブで加俚水熱 作用させ，ついで稀塩酸で可溶性の鉄分の定量を行つ た。この場合加圧水熱条件として, $10 \mathrm{~kg} / \mathrm{cm}^{2}$ より $30 \mathrm{~kg} / \mathrm{cm}^{2}$ の範囲を $5 \mathrm{~kg} / \mathrm{cm}^{2}$ 打きに取り, それぞれ 処理時間を 1 時間, 1 時間半, 3 時間の 3 族に分け, 加圧水熱したものについて稀㙁酸による可溶性鉄分の 定量を行つた。

以上の操作による実験結果を考察してみると，各粘 土試料（入草粘土, 枝下粘土, 豊徳粘土, 土岐口水籍 蛙目）によつて特異な脱鉄率を示している。すなわち

\section{名古屋工業大学 檜 山真 平}

各試料が示した脱鉄率の状態が共通の状態を示さず， 扔の扔の特有の脱鉄率を示しているが，1試料内に括 ける脱鉄率曲線は, 実験処理条件に相違があつても曲 線の反応谁行状態は厳密には差異があるが，傾向とし ては多少同傾向に進んでいることが穿われた。

この傾向について各試料個々について説明したいと 思与 (省略)。

結局本研究による脱鉄状態は

（イ）各加压水熱しだものを，稀塩酸で 1 時間と 3 時間溶解処理して, 除鉄効果を比較検討してみたが, その結果は 3 時間処理した場合の方が効果的であう た。

（ロ）一般に加圧水熱の同一時間内で，加压の増加 に伴い脱鉄率は減少する傾向がある。

（八）この研究範冊内では加圧水熱を施さず，未処 理の粘土試料に直接稀㙁酸で溶解したものと脱鉄率を 比較してみたが，却つて未処理の試料に直接稀塩酸で 溶解した場合の方が脱鉄率の結果はよく現われた。

（二）陶石の脱鉄結果は若干期待し得るる，粘土類 に対して現在行つた $30 \mathrm{~kg} / \mathrm{cm}^{2}$ の 3 時間位の加圧水熱 実験状態では，期待した程の効果は遣憾ながらあげら なれかつた。

\section{7.コバルト・ブラウンに関する研究}

\section{横浜国立大学工学部 $\bigcirc$ 松下 寛・東京大学工学部 山口 悟郎}

原料として水酸化コバルト，アンモニウム明攀，硫 酸第一鉄を用い，これら三成分をそれぞれ適当な割合 に混合，微粉砕し，磁製坩堝に入れ，エレマー师で $800^{\circ} \mathrm{C}$ に加熱生成せる顔料の色調組成と結晶構造相互 の関係を研究した。

組成と色調の関係については，酸化第二鉄の含量と 酸化コバルト, 酸化アルミニウムのモル比が生成物の 色調に大なる影響を示し，酸化コバルトと酸化アルミ ニウムのモル比を一定に保ち, 順次酸化鉄の量を增加 するにつれ，生成物は良色より焦茶色を経て，ベンガ ラ系統への色と变化する。すなわち $590 \mathrm{~m} \mu$ 前後の 主波長を示しつ〉純度は $10 \%$ 前後より $50 \%$ 前後ま で, 明度は 0.04 前後より 0.08 前後まさ增加する。 㕛酸化鉄のモル比を一定にし，酸化コバルトと酸化了
ルミニウムのモル比を変化する系列です, 色調の変化 は, その比を順次 $3: 1,2: 1,1.4: 1,1: 1.1: 1.4$, $1: 2$ と変化させるにつれ, 主波長の特に大なる変化 は無いが, 純度と明度はある一定の变化を示し, 酸化 コバルトのモル数の増加に伴つて, 酸化鉄含量の純度 と明度に扣よぼす影響も増大するのが認められる。

次に, X線的研究の結果によれば, 試料中最も酸化 コバルト含量の大なる系列については，酸化鉄含量の 小なる試料は，むきらかに酸化コバルト・酸化鉄のス ピネル構造を示し, 以下酸化鉄含量の増加と共に酸化 第二鉄の線が強度を增す。な打又, 酸化コバルトと酸 化アルミニウムのモル比の減少につれ, 同一酸化鉄含 量の系列でも, 順次酸化第二鉄の線が強度を增す。又 酸化コバルトに比し酸化アルミニウムの含量の多い系 
列では, 酸化コバルト・酸化アルミニウムのスピネル 構造が認められる。

これらの結果からせきらかなよりに，本実験で生成 したコバルト・ブラウンは, 酸化鉄・酸化コバルトス ピネル, 酸化アルミニウム・酸化コバルトスピネルと 酸化第二鉄の混合物であり, 又上記の各成分の組成と 色調との関係も, これらX線的諸事実から当然の結果 となる。すなわち, 酸化鉄含量の增加と共に゙生ずる色 調の変化は, 酸化コバルト・酸化鉄スピネルの黒色 に酸化第二鉄の赤色が漸次添加されるためであり, 又 酸化コバルト含量の減少に伴い，上記酸化コバルト・
酸化鉄スピネルの告成子減少し，次第に酸化第二鉄是 主体とするベンガラ系統の色が強くなり，又同時に青 色の酸化コバルト・酸化鉄スピネルの黑色に,酸化第二 鉄の赤色が順次加わるためであり, 又酸化コバルトの 減少に伴い, 上記スピネルの含量も減少し, 次第に酸 化第二鉄を主体とするべンガラ系統の色調が強くな り, 又同時に青色の酸化コバルト・酸化アルミニウム スピネルの生成もあり，こ扎らの条件の相互影響によ つて上記のような組成による色調変化を生じている。

な拉,この顔料の陶磁器顔料としての性能その他に ついては, 目下試験中である。

\section{8. 絹雲母の性質と絹雲母一珪石系の研究}

\section{東京工業大学 ○素本 洋一・福 井 博}

最近, 極めて純度の高い絹雲母が塩原に発見された ので, この水籍物について諸性質を研究した。比較の ために, 陶磁器原料としてますます利用されてきた村
上粘土についても水籍物について研究したので, 得ら れた結果を報告する。

$\begin{array}{rcrrrr}\text { 析 } & \text { 值 } & & & & \\ \mathrm{MgO} & \mathrm{K}_{2} \mathrm{O} & \mathrm{Na} \mathrm{N}_{2} \mathrm{O} & \mathrm{H}_{2} \mathrm{O}(+) & \mathrm{H}_{2} \mathrm{O}(-) & \text { Total } \\ 0.16 & 8.62 & 0.45 & 4.89 & 0.72 & 99.96 \\ 0.82 & 5.13 & 0.24 & 5.19 & 1.05 & 99.89\end{array}$

之れら雨者の試料について粒度分析, 熱分析, 加熱 減量, 抢よび比重の変化, 可塑性, 粘性, 並びに各種 温度に拈ける加熱物の熱膨脹, 而酸, 耐アルカリ性を しらべ, 特に $100^{\circ} \mathrm{C}$ から $1400^{\circ} \mathrm{C}$ まで各温度に焼成 した試料について吸水率, 気孔率, 見掛比重, 嵩比重 を測定した。この結果真比重は $500^{\circ} \mathrm{C}$ から急激に減 少し， $1100^{\circ} \mathrm{C}$ まではほとんど一定となり，1200 $\mathrm{C}$ $1350^{\circ} \mathrm{C}$ までのところ極少值があり, $1400^{\circ} \mathrm{C}$ になつて や〉増加を示し, 脱水によつて比重が低下寸ることが あきらかとなつた。膨脹は $1000^{\circ} \mathrm{C}$ 加熱物が最も小さ く, $800^{\circ} \mathrm{C}$ までの焼成物ではまだ絟雲母の性犋があき らかに見られ， X線の結果と類似する。しかして $1200^{\circ} \sim 1250^{\circ} \mathrm{C}$ に焼成したものではクリストバライト
の転移が認められるが， $1300^{\circ} \mathrm{C}$ ではこれが消えてガ ラスになる。この関係は塩原と村上とではや〉異なつ てくるのは，村上粘土中に極く微細な石英が湿在する ためである。可塑性は割合に大きいが，絹雲母の特長 は最高の可塑值を示寸水分範囲が広いことである。

綃零母一珪不系では, 特に陶石の熱的性質の基本概 念を得るために行つたものである。使用原料は尾原セ リサイト，福島珠石および別府白土で，各成分系につ いて，加熱による鈥結の状態を追求し，更に高温の粘 性水和膨脹等をるしらべた。特に著しいことは珠酸原 料の種類によつて燃結の状態が巽なることで, このこ とは陶石を構成する絹雲母のみならず，珪石の種類も 重要な役目をすることである。

\section{9. 金倉廃蠟石釷の精製水笙実験と水䇦物の諸性質}

\section{東京工業大学 素 木 洋一}

本邦には；硫化鉄その他の不純物を含むために捨て られている原料が極めて多い。この研究結果は現在工 業化さ机ているが，一般原料の処理方法に対する一資 料を与えるために要点を報告する。

3 種類に分類, 集積されている廃不（一番坑，“項上，
三㑇小屋）を平均に集め, 風乾試料 $12 \mathrm{~kg}$ に対し $\mathrm{pH}=6.2$ の水 $6 l$ を入れて 1 日放置し, 䚌拌後浮遊 部分を取り，数回くり返す。最後に残椬学 $3 \mathrm{~mm}$ 目節 を通し水洗する。篩に残る部分を尾鉱, 160 mesh (Tyler) に残る部分を中鉱, 通過部分を尾鉱とし、'各 
原鉱についてそれぞれ割合を求め，更に精鉱を $0 \sim 5 \mu$ 5〜15 $\mu$ 抢よび $15 \mu \sim 160$ mesh の三者に分け，これ らの試料について化学分析, 脱水, 熱膨脹, 粘度, 可塑 性, 焼成物の性質を比較して, 耐火物用, 陶磁器用, フイラー用としとの使用可能な範囲をきめた。次に各 粒子径内の化学分析値, 構成鉱物の量を示す。

\begin{tabular}{|c|c|c|c|c|c|c|c|}
\hline $\begin{array}{l}\text { 試 } \\
\text { 顶上< } 5 \mu\end{array}$ & $\begin{array}{c}\text { Ig.loss } \\
4.27\end{array}$ & $\begin{array}{l}\mathrm{SiO}_{2} \\
55.91\end{array}$ & $\begin{array}{c}\mathrm{Al}_{2} \mathrm{O}_{3} \\
33.61\end{array}$ & $\begin{array}{c}\mathrm{Fe}_{2} \mathrm{O}_{3} \\
0.53\end{array}$ & $\begin{array}{l}\mathrm{TiO}_{2} \\
0.30\end{array}$ & $\begin{array}{c}\mathrm{CaO} \\
1.13\end{array}$ & $\begin{array}{l}\mathrm{MgO} \\
0.05\end{array}$ \\
\hline \multirow{3}{*}{ 潘 $\left\{\begin{array}{l}<5 \mu \\
5 \sim 15 \mu \\
15 \mu \sim 160 \#\end{array}\right.$} & 6.82 & 56.09 & 34.45 & 0.18 & 0.35 & 1.10 & 0.05 \\
\hline & 6.26 & 54.89 & 34.48 & 0.35 & 1.18 & 1.46 & 0.09 \\
\hline & $\# 6.64$ & 57.67 & 29.51 & 0.98 & 3.55 & 1.43 & 0.08 \\
\hline \multirow{3}{*}{ 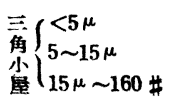 } & 6.52 & 59.38 & 32.36 & 0.68 & 0.25 & 0.70 & 0.08 \\
\hline & 5.64 & 62.49 & 27.93 & 0.78 & 1.35 & 0.85 & 0.10 \\
\hline & \# 5.15 . & .67 .05 & 23.74 & 1.48 & 1.85 & 0.55 & 0.04 \\
\hline 料 & \multicolumn{2}{|c|}{$\mathrm{SO}_{3}{\underset{\mathrm{Al}}{\mathrm{Al}_{2} \mathrm{O}_{3}}}_{\mathrm{S}_{2} \mathrm{~S}_{2}}$} & \multicolumn{2}{|c|}{ SK Pyrophy } & $\begin{array}{l}\text { Dias } \\
\text { pore }\end{array}$ & sil & Silica \\
\hline \multirow{4}{*}{$\begin{array}{l}\text { 項上 }<5 \mu \\
\text { 音 }\left\{\begin{array}{l}<5 \mu \\
5 \sim 15 \mu \\
15 \mu \sim 160\end{array}\right.\end{array}$} & 0.30 & 2.84 & 33 & 87.9 & 6.5 & 0.29 & - \\
\hline & 0.19 & 2.77 & 34 & 87.8 & 7.2 & 0.73 & - \\
\hline & 0.20 & 2.69 & 33 & 86.4 & 8.1 & 0.0 & - \\
\hline & 1.37 & 3.25 & 32 & 90.8 & 0.83 & 0.0 & - \\
\hline \multirow{3}{*}{ 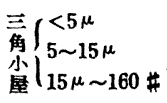 } & 0.22 & 3.06 & 33 & 93.5 & 3.0 & 0.0 & - \\
\hline & 0.26 & 3.81 & 32 & 88.05 & - & - & 6.5 \\
\hline & 0.83 & 4.72 & 31 & 64.9 & - & - & 18.4 \\
\hline
\end{tabular}

加熱減量は微細粒子のものが大きく，熱膨脹は粒度 によつて目立つ床变化はない。 $1300^{\circ} \mathrm{C}$ 加熱物の膨脹 では一番坑のものに差が見られる。狫成温度と気孔率 との関係では微細なるの程烓結が早い。可塑性, 粘性 も微細なもの程大きく，鉱床による差異も見られる。 これらの結果から耐火物用としては 160 mesh 以下， 陶磁器用としては $10 \mu$ 以下，フォラー用としては $5 \mu$ 以下を採取すれば呈色，焼結等からみて使用可能であ る。

次に本実験を基として工場設計を行い，工場操作で 得られた試料について臘石の基本実験を行つた。すな わち化学分析, 粒度分析, 粒度特にテクントロピー, 可塑性, 乾燥収縮, 加熱減量, 熱分析, 加熱温度によ る比重の変化, 熱膨脹の变化, その他の物理的性質の 変化をしらべた。

\title{
30. クローム錫系赤色顔料の製造
}

\section{名古屋市工業研究所 $\bigcirc$ 加藤 健次 - 蟹江 照行}

クローム錫系顔料の陚作試験をしたので, この実験 中に見出した製造条件について報告する。

この顔料は酸化錫，炭酸石灰，珪酸を原料としてい、 るが，これら三成分の調合割合については，先にイン ドの A.N. Bose 氏(Ceramic Age, January 1949, 17) と他に若干の報告があるがその結果は必ずしも一致し ていない。これは, るちろん使用原料の品質, 純度並 びに処理状況の相違によるものと思われる。演者は, その工業化を目的として純度の高い原料は使用しない で，酸化錫は日本金属製を，炭酸石灰は白石工業製 を, 珪酸は小島珪石焼成粉末を使用して, それら三成 分を種々の割合に調合し，その 21 種類について同一 処理操作の下で試験して発色状態を比較し, 更に適当 な同一成分謂合物を選んで, 焼成温度, 焼成時閒, 师 内の雾囲気を種々に变へて発色状態を比較検討して, 適当な製造条件考案した。
この顔料の発色原理機構は, 現在まだあきらがにさ れないが, 丁度カシア紫が色留郕の塩化錫にコロイド 金が分散されて発色すると同様に, この顔料は酸化錫 が色留肪の作用をして，その中に酸代クローム分子が 分散されて発色するすので, 新しい化合物の生成によ るものではないと考えられている。このクローム供給 原料として, 種々の重クローム酸塩とクローム酸塩を 適当な同一原料調合物に混和して，その発色状態の変 化を試験して，適当な㙁を選択した。

そのほかに, 添加刻(硝酸カリ, 酸化鉛等の酸化剒) の混和による発色の影響を試験し，更にこの色基はつ ラックスの組成によつて，かなり色を左右するるの で, 適当なフラックス組成を考案した。

以上の試験結果から従来の製法に一部の改良を案出 した。

\section{1. クロム煉瓦とクロマク煉瓦の重液分離による 鉱物組成の研究}

\author{
東京大学山口悟郎 \\ クロム煉瓦とクロマグ煉瓦を重液分離した結果，つぎに示す比重分布曲線を得た。
}




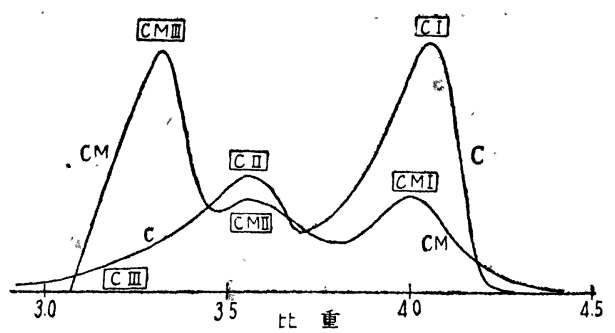

各比重部分の分析結果をつぎに示す。

\begin{tabular}{|c|c|c|c|c|c|c|}
\hline II & $\stackrel{\mathrm{SiO}_{2}}{\underline{-}}$ & $\begin{array}{c}\mathrm{Al}_{2} \mathrm{O}_{\%} \\
31.0\end{array}$ & $\begin{array}{c}\mathrm{FeO} F \\
9.1\end{array}$ & $\begin{array}{r}e_{2} \mathrm{O}_{3} \\
6.9 \\
6.9\end{array}$ & $\begin{array}{r}\mathrm{Cr}_{2} \mathrm{O}_{3} \\
34 . \% \\
34.9\end{array}$ & $\begin{array}{c}\mathrm{MgO} \\
18.1\end{array}$ \\
\hline II & - & 43.1 & 8.8 & 7.2 & 23.5 & 20.0 \\
\hline III & 32.5 & 18.1 & $\begin{array}{l}\mathrm{Fe} \\
22 .\end{array}$ & & 10.8 & 9.1 \\
\hline MI & - & 27.3 & 1.0 & 11.5 & 36.1 & 22.8 \\
\hline CMII & 1.7 & 34.1 & - & 15.5 & 23.3 & 25.6 \\
\hline
\end{tabular}

この各部分を X線分析した結果はつぎの通りであ る。

CI, CII, CMI, CMII……スピネル

CIII …‥ガラス質が大部分で一 部スピネル

CMIII ……フォルステライト

スピネル部分の分析值によつてその組成式を求める と

$$
\begin{aligned}
& \text { CI } \cdots \cdots \cdots(0.78 \mathrm{Mg}, 0.22 \mathrm{Fe}) 0 \cdot(0.53 \mathrm{Al} \text {; } \\
& 0.40 \mathrm{Cr}, 0.07 \mathrm{Fe})_{2} \mathrm{O}_{3} \\
& \text { CII …..... }(0.80 \mathrm{Mg}, 0.20 \mathrm{Fe}) 0 \cdot(0.67 \mathrm{Al} \text {, } \\
& 0.26 \mathrm{Cr}, 0.07 \mathrm{Fe})_{2} \mathrm{O}_{3} \\
& \text { CMI......... (0.98 Mg, 0.0 Fe) } 0 \cdot(0.47 \mathrm{Al} \text {, } \\
& 0.40 \mathrm{Cr}, 0.13 \mathrm{Fe})_{2} \mathrm{O}_{3} \\
& \mathrm{CMII} \cdots \cdots . . . . . \mathrm{MgO} \cdot(0.57 \mathrm{Al}, 0.26 \mathrm{Cr} ; 0.17 \\
& \mathrm{Fe})_{2} \mathrm{O}_{3}
\end{aligned}
$$

$\mathrm{X}$ 線分析結果からこのスピネルの格子常数を求める と CI $8.22 \AA$, CII $8.20 \AA$, CMI $8.23 \AA$, CMII $8.21 \AA$ となつた。

単純スピネルの格子常数として $\mathrm{MgO} \cdot \mathrm{Al}_{2} \mathrm{O}_{3} 8.06$ $\AA, \mathrm{MgO} \cdot \mathrm{Cr}_{2} \mathrm{O}_{3} 8.31 \AA$, $\mathrm{FeO} \cdot \mathrm{Cr}_{2} \mathrm{O}_{3} 8.34 \AA$, $\mathrm{FeO}$. $\mathrm{Fe}_{2} \mathrm{O}_{3} 8.37 \AA$ が知られているが，クロムとクロマグ 煉瓦中では，これから固溶体をなしていることが上の 結果から確められた。またこの固溶体はクロム含有量 の多いるのと少いるのの群に分れているようである。

CIII 部分に見られるよ5に，クロム煉瓦では珪酸 分の多い, ガラス部分が多く在存してその性質を害し ている。

CMIII 部分に見られるようにクロマグ煉瓦では上 の部分が大部分フォルステライト結晶になり，性質を 改善している。

これらの結果はクロム煉瓦とクロマグ煉瓦の性質の 差異を明確に説明している。

\section{2. 高炉シャフト部煉瓦の僈蝕に関する研究}

\section{日本鋼管佐々゙茂式・岩佐宇一・東京工業大学 ○杉浦孝三}

高师用耐火物の侵蝕に関する研究はかなり古くから 行われこれについて幾多の報告がある。例えば A.T.Green") は数基の高师について，それらに使用 された煉瓦の外観变化の肉眼的観察と生成結晶の化学 的, 顕微鏡的観察を行つている。特に注目寸べきは, 同報文中で, 煉瓦はアルカリを吸収することによつて 膨脹を起すが，それが煉瓦崩壊の一因になることを指 摘している。又, L.H. Van Vlack2) は1基の高炬に ついて，同様な研究を行つている。彼は特にアルカリ による侵蝕作用を極めて精細に考察していたが，結論 として, 煉瓦崩壊の原因はアルカ浸蝕とはなんら関 係なく，その主因は炭素沈澱にあるるのとしている。

演者らは日本鋼管川崎工場第 5 高师のシャフト部よ り, 䀡和 25 年 12 月 30 31 日の休風時を利用して 粎 10 種の試料を採取した。作業の都合上,シャフト
の中段部からは試料を採ることができなかつた。今回 は採取することのできた試料のみについて，化学的顕 微鏡的，並びにX線的試験結果を報告する。

シャフト部の下部 3 段までの内側にはコルハート煉 瓦を，それらの外部と 4〜8 段にはシャモット煉瓦を 使用している。

コルハート部分の变質程度は比較的小でむる。すな わち，この部分には，原煉瓦のムライ゙ト又はその分裂 しかけた結晶, コランダムの微粒子群, ムライトの仮 像をなすらしいや人大きなコランダム結晶, 少量のカ リオフィライト，それら結晶の間隙を充填する不透明 の硝子状物質，更にその一部には晶出金属や沈積炭素 の小塊が認められる。むる試料は, 大部分上記のや〉 大きなコランダム結晶によつて占められているが，こ のコランダムはコルハートのできた時から存在したも 